\title{
The Research Competency Improvement Model Based on Integrated Method of Teacher Professional Students in Faculty of Education Udont-Thani Rajabhat University
}

\author{
Somchai Vallakitkasemsakul
}

\begin{abstract}
The purposes of this research were to study and compare classroom action research achievement to study classroom action research ability and attitude toward classroom action research. The sample were 5 year internship students in Faculty of Education at Udon-thani Rajabhat University by cluster random sampling. The research design was applied one group pretest-posttest design. The research instruments were an action exercise book, an achievement-test, a classroom action research ability test and an attitude toward classroom action research test. Analyzed data by mean, standard deviation, percentage, t-test for one sample and t-test for dependent sample. The research results were 1 . The research competency improvement based on integrated methods had 3 steps: Step1 Preparing, Step 2 Doing and Step 3 Sharing. 2. The students had posttest scores higher than the pretest ones. 3. The students had classroom action research ability and attitude toward classroom action research in a good level
\end{abstract}

Index Terms-Competency improvement model, integrated method, teacher professional students.

\section{INTRODUCTION}

Udon Thani Rajabhat University was a local higher education institute of government in Udon Thani province. It had developed from Udon Thani Teachers College, The main duty was to prepare qualified teachers for this area. It has changed role since it was established to be Udon Thani Rajabhat Institute in 1995 and Udon Thani Rajabhat University in 2004. It offerred a variety of management therefore Udon Thani Rajabhat University has to play important roles to prepare good and intelligent teachers.

At present, the functions of Udon Thani Rajabhat University are to provide educational programs, to conduct research for rural development, to preserve and promote arts and culture, to promote academic and professional competence of teachers and educational personnel, and to provide academic services to the community.

Therefore, it is important to focus on developing students to use the research process as a tool to gain knowledge and use as part of the lifelong learning process. The important thing to do is to encourage teachers to integrate research into the learning process and instruction management by enhancing and developing all learners to use the research as part of the learning process and work in order to have

Manuscript received March 1, 2018; revised May 27, 2018.

V. Somchai is with Educational of Faculty, Udon-thani Rajabhat University, Udon-Thani Province, Thailand (e-mail: dr_somchai080707@hotmail.com). self-development, observation skill, searching for answers

From the survey data of students during the teacher professional experience internship, the results showed most students had theoretical knowledge of educational research but they could not apply the principles, concepts, and theories to classroom research in a concrete way efficiently. So the researcher set the goal as follows: students of the Faculty of Education, Udon Thani Rajabhat University should have a development model that will be used in the classroom research and develop students as teachers to have the capacity to apply the principles, concepts and theories they have learned to effective classroom research and decision making in the self-learning process [1].

Therefore, the researcher has set up a model to enhance research capacity based on integrated methods. The concept of workshop is based on research and the active learning process for students to learn together. Students must complete their work after finishing the training (Research Proposal). Then the students will apply the research proposal in real-life situations during teacher professional experience internship under coaching and mentoring concepts, friendly supervision, active learning based on learning by doing under the supervision and consultation of mentors and teachers based on professional learning community ideas to exchange learning and correct the mistakes within the same school or between schools. Each month, during the professional experience internship, teachers will organize seminars for students to reflect on the results of classroom research to see what problems that they have. The students will learn how to solve common problems in a systematic way in order to be able to have research capacity.

The researcher has defined the research questions as follows. 1) Will the students have better understanding of classroom research after the training than before? 2) After using the integrated methods, what are students' attitudes toward classroom research? 3) How will students apply an integrated research model to enhance research capacity?

\section{RESEARCH OBJECTIVES:}

1) To develop research competency improvement model based on integrated methods of teacher internship students, Faculty of Education, Udon Thani Rajabhat University

2) To study and compare classroom research achievement by using research competency improvement model based on integrated methods of students before and after the intervention. 
3) To study classroom research ability using research competency improvement model based on integrated methods of teacher internship students

4) To study attitude toward classroom research using research competency improvement model based on integrated methods of teacher internship students

\section{HYPOTHESIS OF THE RESEARCH}

1) The students who have been using research competency improvement model based on integrated methods have achievement results not less than $80 \%$.

2) The students who have been using research competency improvement model based on integrated methods have posttest scores more than pretest scores.

\section{SCOPE OF THE RESEARCH}

1) Population was the fifth year teacher internship students of Faculty of Education, Udon Thani Rajabhat University

2) Variable of the Research

2.1 Independent variable was research competency improvement model based on integrated methods

\subsection{Dependent Variables were}

2.2.1 classroom research achievement

2.2.2 classroom research ability

2.2.3 attitude toward classroom research

3) Content in training were research methodology, research proposal and classroom research report

4) Research time: first semester of the academic year 2017.

\section{DEFINITION OF TERMS}

1) Research Competency Improvement Model based on integrated methods was actions to create and develop knowledge to provide teacher internship students to exchange experience and create new knowledge continuously.

The emphasis is on two-way interaction between students or between students and teachers / supervisors in order to create learning and expanding the learning network extensively and continuously using research-based learning and active learning under friendly supervision and professional learning community.

\section{1) Stage 1}

Preparing was the process of conducting pre-class training in classroom research with a developed classroom curriculum emphasis on action training ; explain and write research proposal (by group of 3-5 persons). They analyze instruction problems, study learning innovation. The researcher is a facilitator to explain and present the real sample of prototype research report which applies to action. Then let students discuss or question each topic in chapter 1-3. The researcher determined the situation and data for statistical analysis, using statistic package for data analysis and design data analysis presentation based on objectives and hypothesis (Chapter 4), writing summary discussion and suggestions (Chapter 5), and writing references. The researcher presents the issues from the classroom research samples or thesis of graduate students and opportunity for students to ask questions. When students have no questions, students write research proposals and forward to their supervisors who are responsible for supervision during Phase 2 of the research.

\section{2) Stage 2}

Doing was the classroom action research activities of students planned in consultation with students in a group or between groups (Cooperative Learning) and develop work results from working (active learning) and supervision during working with advisors or mentors in real time or internet network or face book (friendly supervision and coaching and mentoring) and activity based on professional learning community.

\section{3) Stage 3}

Sharing was the seminar of teacher internship students during classroom action research based on professional learning community once a month and 4 times for 4 months for the students to reflect on the problems and to study how to solve common problems under the supervision and close consultation of advisors. At the last seminar, students reflected the problems and obstacles in classroom action research and identified the benefits that gained from conducting classroom research.

See Research Competency Improvement Model based on integrated methods in Fig. 1.

\section{Stage 1 Preparing}

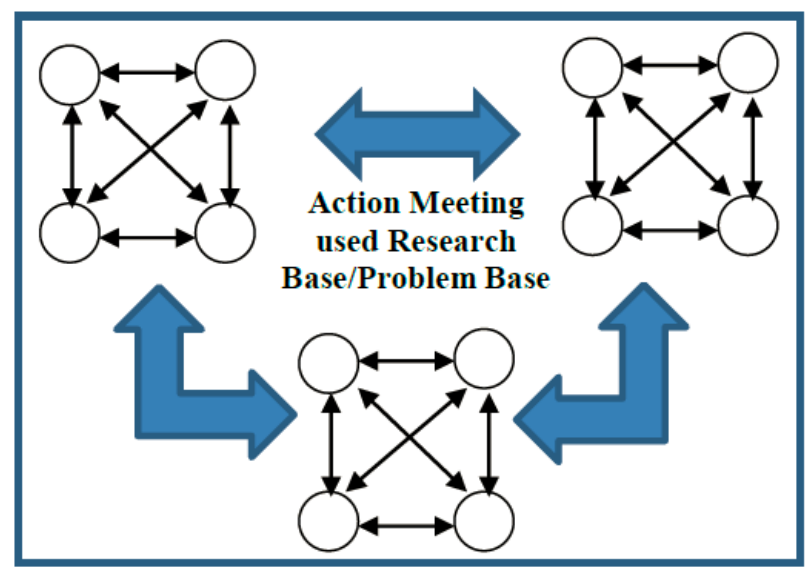

Stage 2 Doing

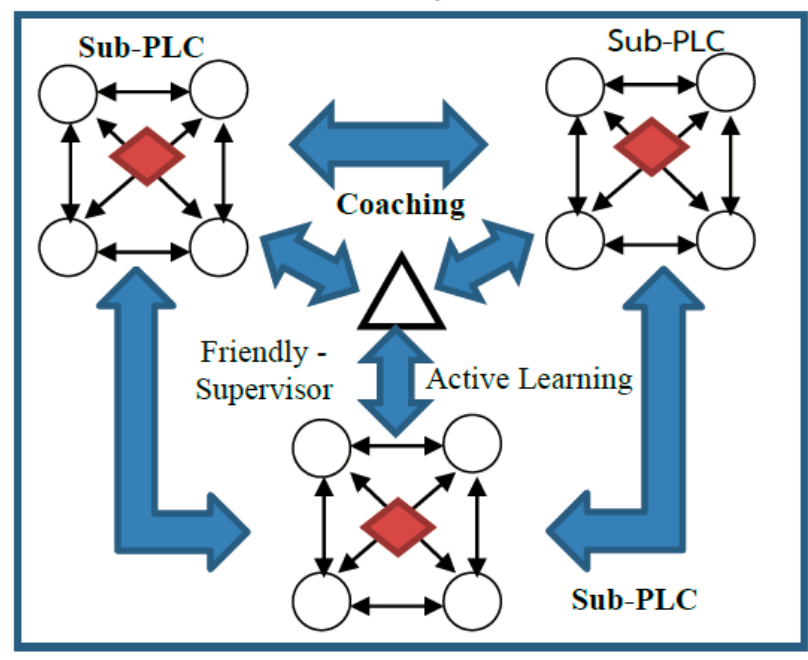




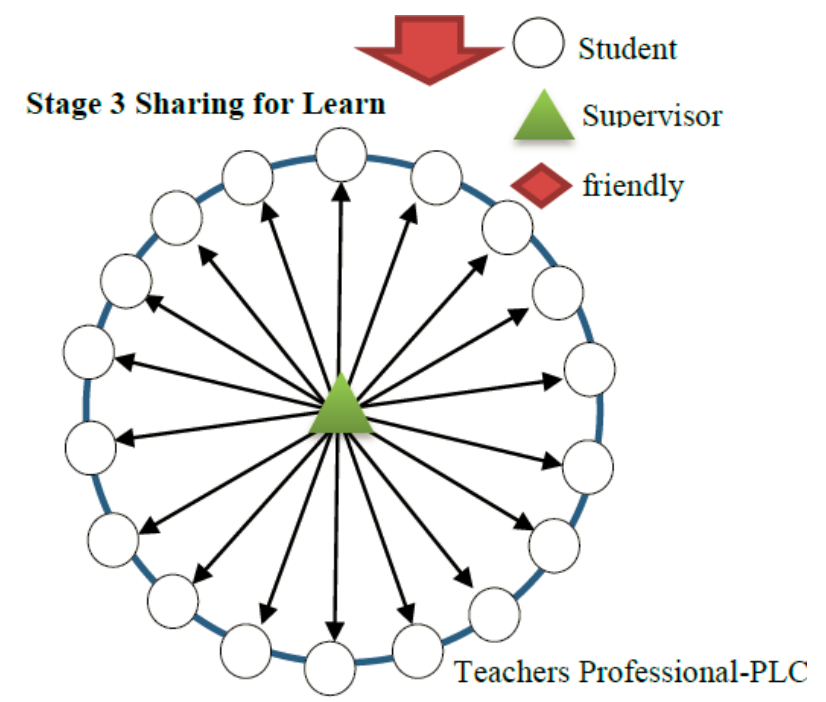

Fig. 1. Research competency model based on integrated methods.

2) Achievement was cognition domain of students measured from achievement test. It was constructed by researcher based on Bloom and Others.

3) Classroom research ability was behavior expressed in doing and writing classroom research report of students from assessment classroom research report by using research form of researcher.

4) Attitude toward classroom research was measured from an attitude test on classroom research.

\section{THE BENEFITS OF THE RESEARCH}

1) Get knowledge about active learning process in teacher production and development. It used the way of teacher internship activity management responded on Education reform and policy setting in new teacher production and development of the Faculty of Education, Udon Thani Rajabhat University.

2) Get the application in the teachers training development and management in the academic service area according to the mission of Faculty of Education, Udon Thani Rajabhat University to prepare teachers for academic works regarding The National Education Act 1999.

\section{ReseARCh METHOdOLOGY}

\section{A. Population and Sample}

The population was the fifth year teacher internship students of Faculty of Education, Udon Thani Rajabhat University.

The sample were 29 fifth year teacher internship Mathematics students, Faculty of Education, Udon Thani Rajabhat University, academic year 2015 by Cluster Random Sampling used classroom as a random unit.

\section{B. Research Design}

This research was a one group pretest-posttest design.

\section{Research Instrument}

1) Research Competency Improvement Model based on integrated methods; emphasis on learning by doing to get work, friendly supervision, coaching and mentoring, and professional learning community which had mean score at 4.53 showed that the research competency improvement model was accurate and appropriate at the highest level.

2) Classroom research achievement test was multiple choice tests with 4 choices, 35 items. IOC equal 1.00 all item, Difficulty of item between 0.35-0.75, Discrimination of item between $0.31-0.73$ and reliability of test equal 0.85

3) Classroom research ability evaluation form scoring by criteria used rubric scoring, classified by quality of work at 5 levels which was very much, much, medium, low and very low, 11 items, IOC equal 1.00 all item and reliability of scoring in classroom research ability equal 0.88

4) Attitude toward a classroom research questionnaire was 5 rating scale, IOC equal 1.00 all item and reliability of questionnaire by Cronbach Alpha Coefficient equal 0.81

\section{Data Collection}

1) Taking pretest of students used a classroom research achievement test

2) Training classroom research

3) Taking posttest of students used a classroom research achievement test

4) Measuring attitude toward classroom research and evaluating classroom research ability

\section{E. Analysis of Data}

1) Analysis of achievement by mean, standard deviation, percent and compare between achievement and criteria not less than 80 percent by t-test for one Sample and compare between pretest score and posttest score by t-test for Dependent Sample.

2) Analysis of classroom research ability score and attitude toward classroom research by mean, standard deviation, percent and translate by mean criteria.

\section{F. Statistics for Analysis of Data}

1) Statistics for analysis quality of research instrument

1.1 Index objective congruence

1.2 Compute difficulty discrimination and reliability by Kuder and Richardson formula of classroom research achievement test

1.3 Compute reliability of attitude toward classroom research by Cronbach Alpha Coefficient

1.4 Compute reliability of classroom research ability scoring by Pearson correlation Coefficient

2) Descriptive statistics: mean, standard deviation and percentage

3) Inferential statistics used hypothesis testing Compare different between achievement and criteria less than $80 \%$ by t-test for one Sample and compare between pretest score and posttest score by t-test for Dependent Sample

\section{RESEARCH RESULTS}

1) Research Competency Improvement Model based on integrated methods classified by 3 stages: 1) stage 1 
prepare 2) stage 2 doing and 3) stage 3 Sharing.

2) The students used Research Competency Improvement Model based on Integrated methods had pretest mean score at 16.48 or 47.90 percent and posttest mean score at 28.62 or 81.86 percent which was not less than $80 \%$.

3) The students used Research Competency Improvement Model based on integrated methods had classroom research ability score at rather good level and had 29 titles of classroom research report: 14 papers were classified as good classroom research report at 48.28 percent and 15 papers as rather good at 51.72 percent

4) The students used Research Competency Improvement Model based on integrated methods had attitude toward classroom research at rather good level.

\section{Discussion}

1) The student have classroom research achievement pretest score equal 16.48 or 47.90 percent and posttest score equal 28.62 or 81.86 and the students have posttest score more than pretest score. For the following reasons:

1.1 The construct and developing this Model. Researcher began by analysis problem from conducting classroom research of teacher. Found: Teachers lack the knowledge to link from theory to practice (From learning innovation to writing a learning plan). Teachers lack understanding of the analysis and presentation of data analysis. Teachers lack understanding of writing classroom research proposal and reports. The important issue is the lack of individuals in the field of classroom research for consultation and advice or non-check during research, so the teacher was unable to proceed on the research. Therefore, the teacher stopped to work on classroom research. From this problem, researchers have studied and designed methodology to solve problems regarding theories and principles and various concepts from aforementioned analysis based on 3 stages of classification: 1) stage 1, Prepare 2) stage 2, doing and 3) stage 3, sharing. Then the researcher asked for suggestions and comments from the experts in order to improve the research design suitable for the assessment model, It was very appropriate used effectively. After that, the researcher applied to 8 students (small group) in the second semester of the academic year 2017. The results of the preliminary investigation in the implementation of the model reflected problems occurred in order to improve the model to use with 29 teacher students internship as a target group.

1.2. The development of this model, the researcher analyzed problems and knowledge to use in the classroom research of teachers at school. Then the researcher designed contents on understanding the classroom research process of the students based on writing research proposal and report. The students learned from the classroom research process from the researcher and exchanged ideas with others. In the meantime, they could ask questions and after that they wrote the research proposals with the emphasis of cooperative learning and two way communication [2][3][4].

It could result in the understanding of classroom research accurately and clearly.

2) The teacher internship students had rather good ability in classroom research with the following reasons: the developing research model emphasis on action activities based on a research manual gave opportunity to ask questions. [5] The research process under friendly consultant and advice from advisors was very productive because of the coaching and mentoring continuously while doing the research and students could reflect and rewrite their proposal to improve their research via facebook and telephone.

Moreover, they could ask questions about the issues that had been advised in classroom research report any time. They could learn from exchange ideas from their friends and their advisors. The atmosphere of doing the research was friendly. The students were not stressful. This consistent with coaching and mentoring and friendly supervision and gave opportunity of learning and exchanging ideas from group discussion mathematics subject in school and had seminars once a month for the students to present their own problems within the same school (2-4 students). This way, students learned from group discussion in solving problems under friendly supervision from their advisors. They learned the way to solve problems from friends through direct experience. This process helped provide understanding and put into practice in conducting their own classroom research effectively based on professional learning community of students [6].

3) The students had attitude toward classroom research in the rather good level. For the following reasons:

3.1 The researcher explained how the classroom research important and necessary according to the national education act 2542; the research played important roles in classroom teaching. And teachers had to do classroom research in order to have academic promotion as well as for self-development into academic positions. The classroom research was evidence portfolio in teachers training experience to receive teacher certificate which was considered to be the achievement of performing classroom research based on an important feature of the professional learning community [7]-[10] .

3.2 This research for development model enhanced the students' ability that researcher could explain knowledge and give classroom research sample or thesis clearly and easy to understand step by step. Then students questioned and practiced under the friendly supervision, coaching and mentoring from mentors and advisors all the time individually and could improve writing their proposal to post on in group face book, which they could receive information to check and improve writing a report by themselves based on friendly supervision and coaching and mentoring [9], [11], [12] and during doing the research, students had seminar with the same group of students for discussion they could help one another. Each month, they had seminar with the same group for presenting problems and methods to solve problems under close of advisors. The students could exchange direct experience from the friends. In addition, they would receive knowledge and understanding in conducting their own classroom research effectively according to the key features of professional learning community [7]-[10]. 


\section{SugGestions}

\section{A. Suggestions for Research Applications}

1) For the department that is responsible for promoting and supporting to use classroom research, they should study and understand the research competency improvement model based on integrated methods for applying in development professional teachers on classroom research.

Especially, supervisors should have sufficient free time for friendly supervision and coaching in schools for consultant and direct advice.

2) Provide a team of research who have knowledge as a mentor in counseling and solve the problems during doing classroom research.

3) Give counseling and advice in doing and solve problems in a variety of methods.

4) Should encourage and admire or cooperate to solve problems rather than criticizing.

5) Should have students prepare classroom research proposal and understanding how to conduct research.

\section{B. Suggestions for Further Study}

1) Should study the retention of research knowledge after completing classroom research report

2) Should study thinking ability during doing classroom research of students such as analytical thinking, synthesis thinking, reasoning thinking or critical thinking etc.

3) Should study classroom research presentation behavior of students by presenting classroom research paper.

\section{ACKNOWLEDGMENT}

I would like to thank Research and Development Institute of Udon Thani Rajabhat University, who give research grant Experts who checking test, scoring research competency, teacher professional students were sample.

\section{REFERENCES}

[1] L. Prukriet, Project Teaching and Research Base Teaching: The Primary Teacher Job, Bangkok: Saha and Son printing co.th., 2009.
[2] S. Thumbumloung, Education Supervision, Bangkok: Vollawutt printing, 1983.

[3] T. Khammani, Teaching Science, Bangkok: Chulalongkorn University Press, 2002

[4] P. Maethakhunnawut, "Instruction base on research process," Paitoon Sinrarath Research Base Instruction, pp. 21-37, Bangkok: Education Faculty, Chulalongkorn University, 2004.

[5] A. Narkorntub, "Learning and research: Teaching using field research process education and social subject education Faculty Chulalongkorn University," Research Base Instructional Articles, Center of Textbooks Education Faculty, Chulalongkorn University, 2002.

[6] K. E. Bulkley and J. Hicks, "Managing community: Professional community in charter schools operated by educational management organizations," Educational Administration Quarterly, vol. 41, no. 2, pp. 306-348, 2005

[7] M. Martin, "Professional learning communities," Contemporary Issues in Learning and Teaching, pp. 142-152, London: SAGE Publications Ltd., 2011.

[8] S. M. Hord, J. L. Roussin, and W. A. Sommers, Guiding Professional Learning Communities: Inspiration, Challenge, Surprise, and Meaning, Corwin Press, 2009.

[9] Annenberg Institute for School Reform. (2013). Professional Learning Communities: Professional Development Strategies That Improve Instruction. [Online]. Available: http://www.annenberginstitute.org/pdf/proflearning.pdf

[10] R. DuFour, "Professional learning communities. "A bandwagon, an idea worth considering, or our best hope for high levels of learning?" Middle School Journal (J1), vol. 39, no. 1, pp. 4-8, 2007.

[11] S. P. Gordon, Professional Development for School Improvement: Empowering Learning Communities, Boston: Pearson, 2004.

[12] P. Maskhal. (2003). [Online]. Available: http://www.humman.rirc.ac.th/pong.htm

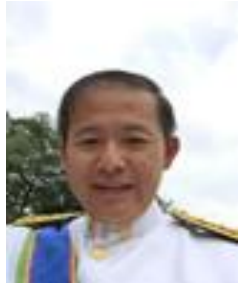

Somchai Vallakitkasemsakul was born on 8 July 1964, Buddha Chinnarat Hospital, Phitsanuloke province, Thailand. He got thte Ed.D. (curriculum research and development) from Srinakharinwirot University, Thailand. In Year B.C.1998. Caree: Associate Professor at Udon-Thani Rajabhat Universit. Research and Evaluation).

Academic performance :

1) V.Somchai. Research Methodology for social science. 5th ed. Undon-thani: Aksornsil printed, 2017.

2) V.Somchai. Education Measurement and Evaluation. 7th ed. Undon-thani Aksornsil printed, 2017

3) V. Somchai. Construction Mathematics Test. Undon-thani: Aksornsil printed, 2016. And

4) V. Somchai. Applied Statistic for Behavioral and Social science research. Undon-thani: Aksornsil printed, 2011 